\title{
Induction of a Serotonergic and Neuronal Phenotype in Thyroid C-Cells
}

\author{
Michael S. Clark, ${ }^{1}$ Thomas M. Lanigan, ${ }^{1}$ Nicole M. Page, ${ }^{2}$ and Andrew F. Russo ${ }^{1,2}$ \\ ${ }^{1}$ Molecular Biology Program and '2Department of Physiology and Biophysics, University of lowa, lowa City, lowa \\ 52242
}

We have Investigated whether rat thyroid $\mathrm{C}$-cells can acquire a phenotype similar to serotonergic neurons. C-cells are neural crest derived endocrine cells with some intrinsic neuronal and serotonergic properties. A relatively simple isolation scheme yielded cultures of about $50 \%$ initial purity, as measured by fluorescence activated cell sorting. These enriched C-cells could extend neurites up to $550 \mu \mathrm{m}$ on a laminin-containing substratum in the presence of NGF. The cultured C-cells expressed neurofilaments and this expression was enhanced by NGF treatment. The C-cells also expressed two markers of the sympathoadrenal neural crest lineage, the mammalian achaete scute homolog-1 (MASH-1) transcription factor, and the B2 cell surface antigen. Interestingly, MASH-1 was not detectable after the C-cells were placed in culture, which is consistent with neuronal differentiation, since MASH-1 is only expressed in neuronal progenitors prior to differentiation. We then demonstrated that $\mathrm{C}$-cells possess the fundamental features of serotonergic neurons: synthesis and secretion, uptake, and feedback control. The enriched C-cells, as well as the CA77 C-cell line, showed 5-HT immunostaining, expression of tryptophan hydroxylase mRNA, 5-HT ${ }_{1 \mathrm{~B}}$ autoreceptor mRNA, and 5-HT transporter mRNA and activity. NGF greatly induced 5-HT transporter activity as determined by sensitivity to sertraline, a selective 5-HT reuptake inhibitor. Based on these results, we propose that thyroid C-cells are derived from a vagal sympathoadrenal progenitor, similar to serotonergic enteric neurons, and can undergo neuronal transdifferentiation. Hence, these cells should provide suitable and convenient models for molecular and cellular studies on serotonergic neurons.

[Key words: thyroid C-cell, parafollicular cell, calcitonin, 5-HT, neural crest, neuronal differentiation]

The neural crest gives rise to a diversity of cell types, including the endocrine thyroid C-cells (parafollicular cells) (LeDouarin et al., 1974; Polak et al., 1974; LeDouarin, 1982). C-cells are

\footnotetext{
Received Feb. 20, 1995; revised May 10, 1995 accepted May 16, 1995

We thank Karla Daniels for helpful advice on immunostaining, Hadassah Tamir for generously performing analyses of serotonin content and release in CA77 cells, Austin Garza for his assistance in the autoreceptor characterization, and Maya Sieber-Blum, Hadassah Tamir, and Michael Gershon for helpful and interesting discussions. This work was supported by NIH Grant HD25969, with tissue culture support from the Diabetes and Endocrinology Center (DK25295) antibodies obtained from the Developmental Studies Hybridoma Bank (HD23144), and an institutional MSTP predoctoral fellowship training grant (GM07337) and an individual NIMH NRSA (MH10752) to M.S.C.

Correspondence should be addressed to Andrew Russo, Department of Physiology and Biophysics, University of Iowa, lowa City, IA 52242.

Copyright $C 1995$ Society for Neuroscience $0270-6474 / 95 / 156167-12 \$ 05.00 / 0$
}

distinguished by their expression of the hormone calcitonin (CT), yet they retain some neuronal properties. Most noteworthy are their serotonergic properties, including a neuron-specific serotonin binding protein and serotonin (5-hydroxytryptamine, 5-HT) biosynthetic enzymes (Nunez and Gershon, 1972; Barasch et al., 1987b), as well as the ability to extend processes in response to NGF (Barasch et al., 1987a) and on laminin (Nishiyama and Fujii, 1992). C-cell lines have also been shown to express neuronal and serotonergic markers including tryptophan hydroxylase, monoamine oxidase $\mathrm{A}$, and fluoxetine inhibitable 5-HT uptake activity (Tamir et al., 1989; Russo et al., 1992; Clark et al., 1994, 1995). These properties are of particular interest due to the involvement of serotonergic systems in a wide variety of physiologic processes and psychiatric disorders (Azmitia and Whitaker-Azmitia, 1991).

The serotonergic properties of C-cells are reminiscent of enteric neurons. Both $\mathrm{C}$-cells and enteric neurons are derived from the vagal neural crest (LeDouarin, 1982). The C-cell progenitors appear to initially comigrate with the enteric neuroblasts into the branchial arch mesenchyme (LeDouarin, 1982; Ciment and Weston, 1983, 1985; Payette et al., 1984; Ito and Sieber-Blum, 1991, 1993). The shared origin and migration pathways of C-cells and enteric neurons has raised the speculation that these cells arise from a common progenitor (Barasch et al., 1987; Tamir et al., 1989; Anderson, 1993). Enteric neurons have been proposed to arise from a sympathoadrenal progenitor (Baetge et al., 1990; Carnahan et al., 1991), which has been well documented as the precursor to sympathetic neurons and adrenal chromaffin cells (Anderson, 1993). One marker of sympathoadrenal progenitors is the mammalian achaete-scute homolog 1 (MASH-1) transcription factor. MASH- 1 is expressed in neuronal progenitors, including sympathoadrenal precursors, but not in neurons after differentiation (Johnson et al., 1990; Lo et al., 1991). Therefore, the repression of MASH-1 expression is indicative of neuronal differentiation in sympathoadrenal progenitors. Another marker is the sympathoadrenal-specific B2 antigen. B2 is expressed transiently in sympathoadrenal derived cells, such as prechromaffin cells and enteric neuroblasts (Anderson and Axel, 1986; Carnahan et al., 1991).

In this report, we have tested the hypothesis that juvenile rat C-cells possess serotonergic neuronal transdifferentiation capability. We speculated that NGF might induce neuronal features in rat C-cells based on the studies by Barasch et al. (1987a) on sheep C-cells, and in analogy with NGF effects on adrenal chromaffin cells (see Anderson, 1993). We have demonstrated NGF enhancement of neuronal morphology and neurofilament expression. In support of this acquisition of neuronal properties, 
we have provided evidence that $\mathrm{C}$-cells arise from a sympathoadrenal progenitor, similar to enteric neurons. Furthermore, the temporal regulation of MASH-1 expression is consistent with neuronal differentiation. Finally, we have shown that NGF enhances serotonergic properties, as exemplified by an increase in sertraline inhibitable uptake of 5-HT. These studies suggest that $\mathrm{C}$-cells arise from a sympathoadrenal progenitor and may provide a useful model serotonergic system.

\section{Materials and Methods}

Thyroid primary cultures. Thyroids were dissected from $10-25 \mathrm{~d}$ old male or female rats (Sprague-Dawley or Long-Evans) killed by $\mathrm{CO}_{2}$ asphyxiation, and immediately placed in ice-cold Dulbecco's phosphatebuffered saline (PBS). Excess tissue was trimmed and thyroids were cut into millimeter-sized pieces. These were incubated in $1 \times$ dispase (Boehringer Mannheim, Indianapolis, IN), $1 \mathrm{mg} / \mathrm{ml}$ collagenase P, with $5 \mathrm{~mm}$ $\mathrm{CaCl}_{2}$ (Boehringer Mannheim, Indianapolis, IN) for $30 \mathrm{~min}$ at $37^{\circ} \mathrm{C}$. The mixture was then pipetted to break up large clumps, reincubated for an additional $30 \mathrm{~min}$, and again pipetted. Cells were spun down for $5 \mathrm{~min}$ at $100-250 \times \mathrm{g}$ and resuspended in $2 \mathrm{ml}$ of medium containing DMEM (low glucose): Ham's F-12 (1:1), 10\% felal bovine serum (Hyclone, Logan, UT), and antibiotics $(200 \mathrm{U} / \mathrm{ml}$ penicillin, $200 \mu \mathrm{g} / \mathrm{ml}$ streptomycin) (GIBCO, Gaithersburg, MD), plated onto $35 \mathrm{~mm}$ plastic dishes coated with either fibronectin (Collaborative Research Inc., Bedford, MA) or PYS matrix. Cultures were treated immediately with 100 ng/ml 2.5 S NGF (Collaborative Research Inc., Bedford, MA). In some experiments, $50 \mathrm{ng} / \mathrm{ml} 2.5 \mathrm{~S} \mathrm{NGF}$ was used, with results identical to those obtained using $100 \mathrm{ng} / \mathrm{ml}$. After the cells had settled overnight onto the fibronectin or PYS matrix coater dishes, $4 \mu \mathrm{g}$ laminin (Sigma, St. Louis, MO) was added in the medium of NGF treated cultures. Laminin was also added to control cultures. Cytosine $\beta$-D-arabinofuranoside (Ara-C) added to $10 \mu \mathrm{M}$ to all cultures, and in some experiments, the antifungal fungizone $(0.25 \mathrm{mg} / \mathrm{ml})$ (GIBCO, Gaithersburg, MD) was added. All animals were handled in accordance with state and federal regulations governing the use of animals in research, as well as the Society for Neuroscience statement on the use of animals in research.

PYS matrix preparation. Parietal yolk sac teratocarcinoma cells (PYS cells) (Leivo et al., 1983) were seeded onto $35 \mathrm{~mm}$ plastic dishes and grown for $7 \mathrm{~d}$ in medium containing DMEM (high glucose), $10 \%$ fetal bovine serum (Hyclone, Logan, UT), and antibiotics (200 U/ml penicillin, $200 \mu \mathrm{g} / \mathrm{ml}$ streptomycin) (GIBCO, Gaithersburg, MD). Cells were grown for $7 \mathrm{~d}$ after which the cells were removed by washing for $10 \mathrm{~min}$ at $37^{\circ} \mathrm{C}$ with a $0.75 \%$ FDTA in Farle's Balanced Salt (EBS) solution. The cells were aspirated, and the plate was extensively washed with EBS. The plates were frozen at $-20^{\circ} \mathrm{C}$ until ready for use. Immediately before use, plates were sterilized by exposure to UV light for $30 \mathrm{~min}$.

Immunohistochemical staining. The medium was aspirated and cell cultures were fixed in $4 \%$ parafornaldehyde in PBS for $30 \mathrm{~min}$ at room temperature. The fixed cells were rinsed with $0.2 \mathrm{M}$ Tris-Cl, $0.1 \mathrm{M}$ glycine pH 7.5 for $2 \mathrm{~min}$, and then blocked for $10 \mathrm{~min}$ in PBS with $2 \%$ bovine serum albumin (BSA). For neurotilament and 5-HT staining, cells were fixed in either methanol:acetone (1:1) or methanol:dimethylsulfoxide $(1: 4)$ chilled to $-20^{\circ} \mathrm{C}$. Cells were fixed for $2 \mathrm{~min}$ at room temperature, and residual fix allowed to evaporate. Prior to use, the cells were rehydrated with either PBS with $2 \%$ BSA or PBS with $1 \%$ horse serum (PBS/HS) for $10 \mathrm{~min}$. Polyclonal rabbit antiserum against rat calcitonin was generously provided by Dr. Ian Dickerson, University of Miami, and used at a 1:500 dilution. Monoclonal mouse antibody NN 18 against the $160 \mathrm{kDa}$ neurofilament (NF-M) (Boehringer Mannheim, Indianapolis, IN) was used at a 1:4 dilution. Rabbit polyclonal serum against 5-HT was obtained from Chemicon Inc. (Temecula, CA), and used at a dilution of 1:60. Antibodies were diluted in either PBS with $0.1 \%$ BSA (PBS/BSA), or in PBS/HS. The LA4 and B2B1 mouse monoclonal antibodies were used undiluted from the supernatant obtained from the Developmental Studies Hybridoma Bank (University of Iowa). The MASH-1 antibody (Lo et al., 1991) was used undiluted. The fixed cells were stained with the antibodies overnight at $4^{\circ} \mathrm{C}$. In later experiments, comparable results were seen after staining for $2 \mathrm{hr}$ at room temperature. Cells were then washed $(3 \times 15 \mathrm{sec}$, then $3 \times 3$ min) with PBS/BSA or PBS/HS. FITC-conjugated anti-rabbit and rhodamine-conjugated anti-mouse secondary antibodies (Organon Teknika Corp., Durham, NC; 1:900 dilution) were applied for $30 \mathrm{~min}$ at $4^{\circ} \mathrm{C}$, followed by repeated washes with PBS/BSA, and then mounted with Vectashield (Vector Laboratories). For some experiments Cy3-conjugated anti-rabbit and anti-mouse secondary antibodies were used (Jackson ImmunoResearch, West Grove, PA) at 1:10 dilution. The eclls were analyzed using a Leitz Diaplan fluorescent microscope. For some neurofilament and 5-HT staining, horseradish peroxidase (HRP) conjugated anti-mouse IgG (Sigma, St. Louis, MO; 1:200 dilution) or anti-rabbit IgG (Sigma, St. Louis, MO; 1:150 dilution) were applied for 30 min at room temperature, followed by repeated washes with PBS/HS, and stained with a diaminobenzidine peroxidase substrate kit using $\mathrm{Ni}^{2+}$ enhancement (Vector Laboratories, Burlingame, CA) as per the manufacturer's instructions. In some experiments, HRP conjugated antibodies were preadsorbed as $10 \times$ stocks, to reduce background, by adding to methanol:acetone fixed CA77 cells for $30 \mathrm{~min}$ at room temperature. As controls, the primary or secondary antibodies were omitted. For thyroid sections, rat tracheae were dissected from 10-25 d old male or female rats (Long-Evans) killed by $\mathrm{CO}_{2}$ asphyxiation, immediately placed in ice-cold $4 \%$ paraformaldehyde in PBS ( $\mathrm{pH} 7.4$ ), and fixed overnight at $4^{\circ} \mathrm{C}$. They were then embedded in periplast. Seven micrometer thick slices were deparaffinized in histosol (National Diagnostics, Atlanta GA) and rehydrated using sequential ethanol/water baths. Immunostaining was performed as for the cell cultures. Confocal microscopy was performed as previously described (Swiderski et al., 1994).

RT-PCR and filter hybridizations. Isolation of poly(A) enriched RNA from CA77 cells and total RNA from primary cultures was done using the proteinase $\mathrm{K}$-oligo (dT) chromatography and acid guanidine phenol extraction procedures, respectively, as previously described (Russo et al., 1992). All RNA from primary cultures was isolated from cells cultured on fibronectin and laminin substratum. The RT-PCR reactions were performed essentially as previously described (Crawford et al., 1993). First strand cDNA was synthesized from usually $5 \mu \mathrm{g}$ total or $0.1 \mu \mathrm{g}$ poly(A) RNA with AMV reverse transcriptase using specific primers listed below. A $2.5 \mu \mathrm{l}$ aliquot of cDNA was PCR amplified in a $50 \mu \mathrm{l}$ reaction containing $20 \mathrm{~mm}$ Tris $-\mathrm{HCl}, \mathrm{pH} 8.6,50 \mathrm{~mm} \mathrm{KCl}, 2.5$ $\mathrm{mm} \mathrm{MgCl}_{2}, 30 \mu \mathrm{g} / \mathrm{ml}$ bovine serum albumin, $200 \mu \mathrm{M}$ deoxynucleotides, $0.5 \mu \mathrm{M}$ each of downstream and upstream primers, $1.25 \mathrm{U}$ of Taq polymerase (Boehringer Mannheim, Indianapolis, IN). In order to reliably amplify 5-HT transporter, it was necessary to use semi-nested PCR. For these reactions, reverse transcription was performed using the downstream primer, bases 1537-1450, followed by amplification using this primer and the upstream primer below. A $2.5 \mu \mathrm{l}$ aliquot of the resulting amplification products were then amplified again using the downstream primer corresponding to bases 1161-1176 and the same upstream primer as in the first reaction. Upstream and downstream primer sequences are given in Table 1

The reactions were amplified for 30 cycles at $94^{\circ} \mathrm{C}$ for $1.5 \mathrm{~min}, 55^{\circ} \mathrm{C}$ for $1 \mathrm{~min}, 72^{\circ} \mathrm{C}$ for $2 \mathrm{~min}$, and a final $5 \mathrm{~min}$ incubation at $72^{\circ} \mathrm{C}$. Amplification products were checked by electrophoresis on a $2 \%$ agarose gel. Southern blots and hybridizations were performed as previously described (Crawford et al., 1993). cDNA probes were radiolabeled by random priming (Boehringer Mannheim, Indianapolis, IN) with $\alpha^{32} \mathrm{P}-$ dATP (Amersham) as described (Russo et al., 1992) using either the intact NF-L plasmid (Russo et al., 1992), gel purified TPH fragment from plasmid, or a gel-purified NF-L, NF-M, 5-HT- ${ }_{1 \mathrm{~B}}$, or 5-HT transporter RT-PCR amplification products from rat brain. RT-PCR products were confirmed by dideoxy-sequencing using Sequenase (United States Biochemical, Cleveland, $\mathrm{OH}$ ) following subcloning, or by direct dideoxy-sequencing of the PCR product using Taq polymerase (Stratagene, La Jolla, CA), as recommended by the manufacturers.

5-HT uptake. Primary cultures were prepared as above and plated at a density of 2 thyroids per $35 \mathrm{~mm}$ fibronectin coated dish. Cultures were treated with either NGF and laminin as described above or with vehicle only for $5 \mathrm{~d}$. CA77 cells were plated on untreated $35 \mathrm{~mm}$ dishes and grown to approximately $75 \%$ confluency. Media was aspirated from the plates and replaced with $1 \mathrm{ml}$ of DMEM (low glucose) with $100 \mu \mathrm{M}$ pargyline (Sigma, St. Louis, MO) and $0.5 \mu \mathrm{M}{ }^{3} \mathrm{H}-5-\mathrm{HT}$ creatinine sulfate complex $(10.5 \mathrm{Ci} / \mathrm{mmol}$, Amersham, Arlington Heights, IL) in either the presence or absence of $5 \mu \mathrm{M}$ sertraline (Pfizer, New York, NY), prewarmed to $37^{\circ} \mathrm{C}$. Plates were then incubated at $37^{\circ} \mathrm{C}$ for $20 \mathrm{~min}$. As a negative control, plates were chilled on an ice-water slurry for 10 min, the media replaced with ice-cold DMEM with pargyline and ${ }^{3} \mathrm{H}$ 5 -HT, and incubated on ice for $20 \mathrm{~min}$. The uptake was halted by placing the plates onto an ice-water slurry, aspirating the media, washing twice with ice-cold PBS, followed by addition of $1 \mathrm{ml}$ of ice-cold 0.1 $\mathrm{M} \mathrm{HClO}_{4}$. The cells were then scraped and transferred to a $5 \mathrm{ml}$ culture 


\begin{tabular}{|c|c|c|}
\hline Rat primer & Bases & Sequence \\
\hline \multicolumn{3}{|c|}{ Downstream primer sequences } \\
\hline$\beta$-actin & $1278-1301$ & 5'GATCTTGATCTTCATGGTGCTAGG3' \\
\hline CT/CGRP exon 4 & $618-637$ & 5'ACCCATAATAGCCCAGAGAA3' \\
\hline NF-L & $735-755$ & 5'CTGGACGTGGCTGGTATAGTA3' \\
\hline NF-M & $986-1006$ & 5'CGACTCGAGCTCAATGCTCTT3' \\
\hline MASH- 1 & $1601-1621$ & 5'ATCTAAGTCCTGGTGCCCGT3' \\
\hline ТPH & $1323-1338$ & 5'TTCACACACTGGGCCA3' \\
\hline $5 \cdot \mathrm{HT}_{1 \mathrm{~B}}$ & $1135-1158$ & 5'ACCTGTGCACTTAAAGCGTATCAG3' \\
\hline $5-\mathrm{HT}_{1 \wedge}$ & $1228-1248$ & 5'CTTGATTATCTTGTTAAAAGC3' \\
\hline 5-HT transporter & $1437-1450$ & 5'AGCAGAGTCACCACGT3' \\
\hline 5-HT transporter & $1161-1176$ & 5'CTTTGGCCACCTCTGA3' \\
\hline \multicolumn{3}{|c|}{ Upstream primer sequences } \\
\hline$\beta$-actin & $538-561$ & 5'TTGTAACCAACTGGGACGATATGG3' \\
\hline CT/CGRP exon 3 & $303-323$ & 5'ATGCAGATGAAAGTCAGGGA3' \\
\hline NF- $L$ & $111-131$ & 5'CAGGCTCAGATCCAGTATGCT3' \\
\hline $\mathrm{NF}-\mathrm{M}$ & $380-399$ & 5'CAGAACAAGGAGATCGAGGCA3' \\
\hline MASH-1 & $1326-1346$ & 5'CAACGACTTGAACTCTATGG3' \\
\hline TPH & $942-971$ & 5'TTCACTGTGGAGTTTGGACTGTGCAAGCAA3' \\
\hline $5-\mathrm{HT}_{1 \mathrm{~B}}$ & $855-879$ & 5'GTCAAAGTGCGAGTCTCAGACGCC3' \\
\hline $5-\mathrm{HT}_{1 \mathrm{~A}}$ & $1016-1038$ & 5'TGAAAGGAAGACGGTGAAGACT3' \\
\hline 5-HT transporter & $609-624$ & 5'AACTACTTCGCCCAGG3' \\
\hline
\end{tabular}

tube. Remaining cells from the plates were removed with an additional $0.5 \mathrm{ml}$ of ice-cold $0.1 \mathrm{M} \mathrm{HClO}_{4}$ wash as above. The cells were then homogenized in a Tissumizer (Tekmar, Cincinnati, $\mathrm{OH}$ ) with a $8 \mathrm{~mm}$ probe set at $80 \%$ power for $30 \mathrm{sec}$, pelleted at $2000 \times \mathrm{g}$ for $15 \mathrm{~min}$, and $1.3 \mathrm{ml}$ of the supernatant counted by liquid scintillation using Biosafe II LSC cocktail (Research Products International, Mt. Prospect, IL). For some experiments with CA77 cells, fluoxetine $(5 \mu \mathrm{M})$ (Eli Lily, Indianapolis, IN) was used in place of sertraline.

Fluorescence activated cell sorting. Primary cultures were prepared as above from 25-30 rat thyroids and treated with NGF for $3 \mathrm{~d}$. Medium was aspirated from the cultures, approximately $2 \mathrm{ml}$ of $0.5 \%$ trypsin, $5.3 \mathrm{~mm}$ EDTA solution (GIBCO, Gaithersburg, MD) was added per 100 $\mathrm{mm}$ dish for about $1 \mathrm{~min}$ to produce a single cell suspension. The cell suspension was transferred to a $15 \mathrm{ml}$ conical tube, and any cells remaining on the plate were collected by gently tapping the plate and then rinsing with a small amount of trypsin-EDTA. Cells were spun at $300-500 \times g$ for approximately $5 \mathrm{~min}$. Total time in trypsin was about $10 \mathrm{~min}$. Trypsin was aspirated off the cells and $10 \mathrm{ml}$ of undiluted LA4 antibody in the hybridoma culture supernatant containing $5 \%$ fetal bovine serum was added. The cells were gently pipetted to mix with antibody and break up any clumps, then incubated while gently rotating for $30 \mathrm{~min}$ at $4^{\circ} \mathrm{C}$, spun down as before, and washed for $5 \mathrm{~min}$ at $4^{\circ} \mathrm{C}$ with PBS/BSA. After removal of the PBS/BSA, cells were mixed and incubated for $30 \mathrm{~min}$ at $4^{\circ} \mathrm{C}$ with $10 \mathrm{ml}$ of FITC-conjugated anti-mouse secondary antibody (Organon Teknika Corp., Durham, NC; diluted 1:900). Cells were washed in PBS/BSA, and resuspended in $200 \mu \mathrm{I}$ PBS/BSA, making sure to pipette thoroughly to remove any cell clumps. The cells were then analyzed using a Coulter EPICS 753 Cell Sorter (University of Iowa Flow Cytometry Facility) and collected in growth medium. The high fluorescence population (indicated by the right bar in Fig. $1 E$ ) generally contained $2-8 \times 10^{4}$ cells, which was about $35 \%$ of the events detected by the cell sorter.

\section{Results}

Preparation of an enriched C-cell population

We have established conditions to obtain and culture a relatively enriched population of C-cells from rat thyroid glands. This was a necessary since C-cells comprise only a few percent of the thyroid and the non-C-cells impaired neurite extension from cocultured CA77 cells (data not shown). The only other published C-cell purification procedure involves a negative selection using phagocytosis of thyroglobulin by follicular cells and centrifugation (Barasch et al., I987a). While this procedure has merits, it would have been difficult to adapt it for the smaller number of cells available from rat thyroids. The approach that we took was to determine primary isolation and culture conditions that minimized non-C-cell survival while maintaining $\mathrm{C}$-cell viability. Overgrowth of non-C-cells after prolonged culture proved a significant problem. Since C-cells did not appear to proliferate under culture conditions, we used cytosine $\beta$-D-arabinofuranoside (Ara-C), a cytotoxic agent used to prevent fibroblast overgrowth in primary cultures of other cell types (Gard and Lazarides, 1980). Inclusion of $40 \mu \mathrm{M}$ Ara-C reduced non-C-cell proliferation to a level permissible for subsequent studies, without any noticeable effects on C-cells. A serendipitous finding was that the non-C-cells were relatively sensitive to proteases compared to the C-cells. Immediately following dissociation, about $50 \%$ of the cells were C-cells based on visual detection of calcitonin immunostaining. In addition, under phase contrast microscopy, the C-cells appeared phase bright and round, and were easily distinguished from phase dark non-C-cells (presumably follicular cells and/or fibroblasts).

As a more quantitative measure of $\mathrm{C}$-cell abundance, the relative number of $\mathrm{C}$-cells in the protease treated cultures was determined by fluorescence activated cell sorting (FACS). The LA4 antibody recognizes a glycolipid present on a subset of neural crest-derived dorsal root ganglion neurons (Dodd and Jessel, 1985; Chou et al., 1989), and we had previously found LA4 to stain the CA77 cells (Russo et al., 1992). As expected, LA4 immunoreactivity was specifically observed on the C-cells in the thyroid primary cultures (Fig. $1 A, B$ ). LA4 was chosen for FACS selection since the glycolipid it recognizes would not be altered by protease treatment. The population indicated by the combination of the bars in Figure $1 E$ usually contained $50 \%$ of the cells, which was consistent with the estimates based on light and fluorescence microscopy. Consequently, significant enrich- 
CT

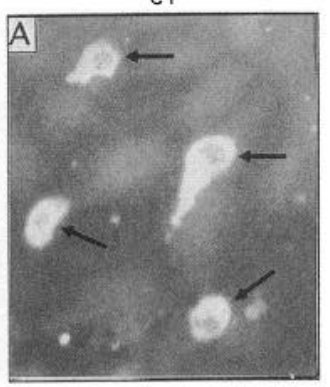

Forward Scatter

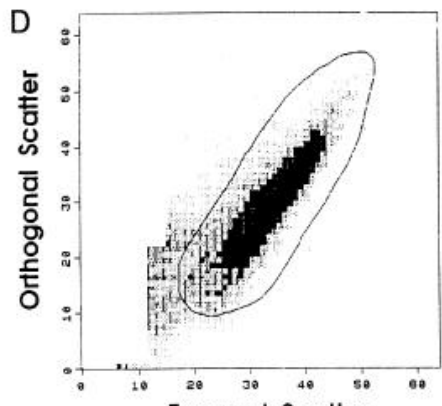

LA4
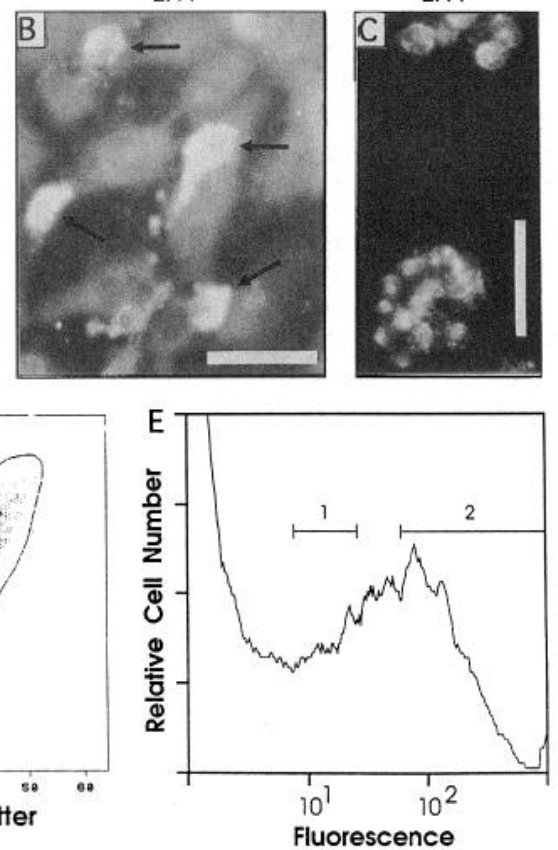

Figure 1. Fluorescent activated cell sorting analysis of enriched C-cell cultures. $A$ and $B$, Fluorescence micrographs of thyroid primary cultures double-stained with CT antiserum $(A)$ and LA4 antibody $(B)$. The LA4 and $\mathrm{CT}$ antigens were detected with FITC and rhodamine conjugated secondary antibodies, respectively. The double stained cells are indicated by arrows. $C$, Fluorescence micrograph of LA4 stained cells about $1 \mathrm{hr}$ after separation by FACS (high fluorescence group). Only fluorescent cells are present in this field. The cells tended to clump together when not attached. $D$, FACS profile showing the population that was selected for sorting based on forward scatter (size) and orthogonal scatter (internal complexity) of fluorescent events. $E$, FACS profile of the relative number of cells and relative fluorescence. The fluorescent population (about $50 \%$ of the cells) was split into two bins, with the low fluorescence group ( $\mathrm{bar}$ l) containing both C-cells and non-C-cells, and the high fluorescence group (35\% of the cells) (bar 2) containing greater than $90 \%$ C-cells. Magnification bars, $50 \mu \mathrm{m}$.

ment of C-cells could be achieved by sequential protease treatments and hence this procedure was used for subsequent studies. Complete removal of non-C-cells by FACS was not considered practical or particularly desirable since C-cells appear to preferentially attach to non-C-cells.

\section{NGF induction of neurites and neurofilaments in thyroid C-cells}

We then asked whether isolated C-cells could extend neurites. The cells were plated on fibronectin or PYS matrix coated dishes. PYS is a parietal yolk sac teratocarcinoma cell line which produces extensive extracellular matrix, including collagen type IV, laminin, and heparin sulfate proteoglycan (Leivo et al., 1983). After plating of the cells, additional laminin was added to the cultures since we and others have noted that laminin promotes neurite outgrowth from C-cells (Nishiyama and Fujii, 1992; Russo et al., 1992). Laminin was also added to control cultures with no apparent effect on morphology or neurofilament expression. After $5 \mathrm{~d}$ of NGF treatment, processes of greater than $10-15 \mu \mathrm{m}$ could be seen by light microscopy on $52 \%$ of the individual $\mathrm{C}$-cells on PYS matrix-coated plates (cell body diameters were 10-15 $\mu \mathrm{m}$ ) (Fig. 2). Processes of greater than $50-75 \mu \mathrm{m}$ could be seen on $11 \%$ of the cells, with approximately half of these extending $100 \mu \mathrm{m}$ or longer. The neurites
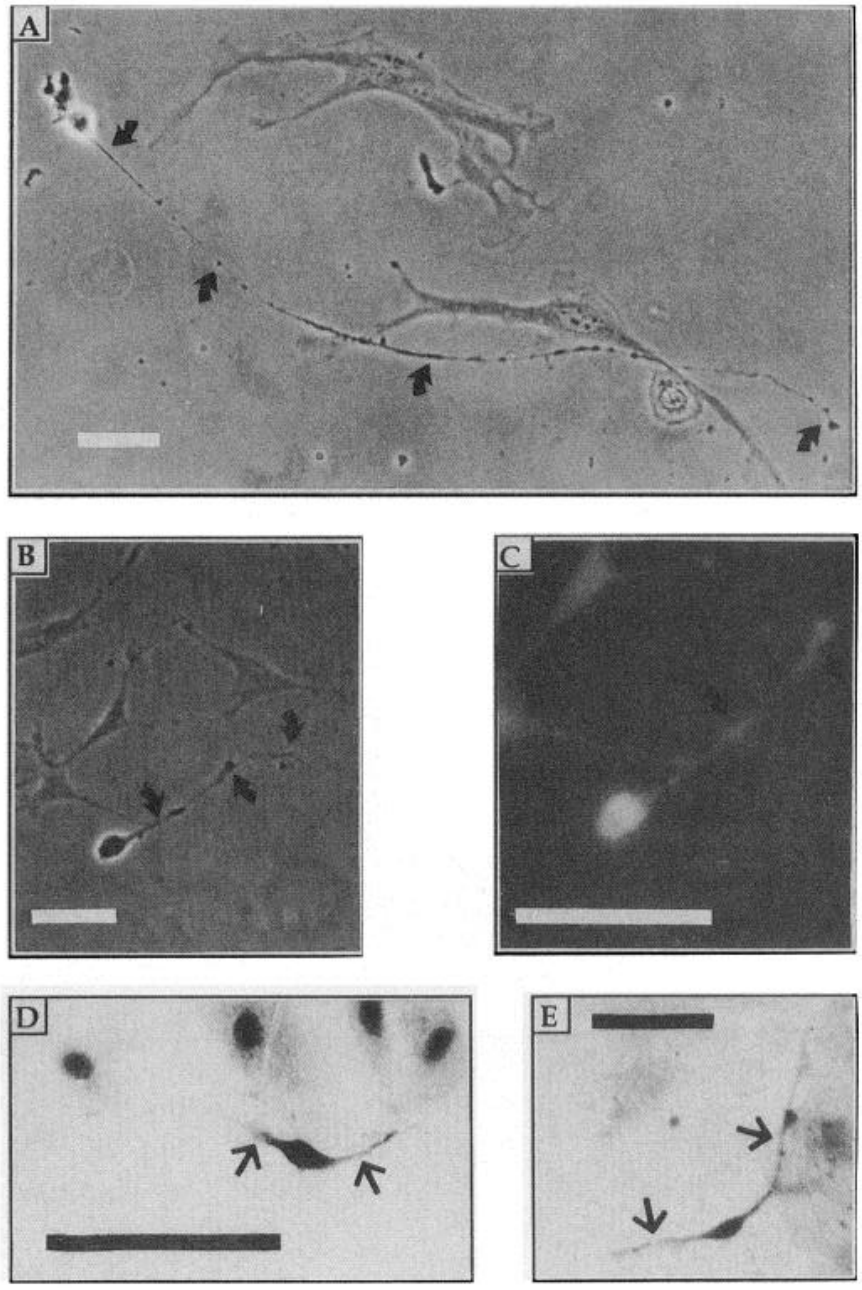

Figure 2. Neurite extension by enriched C-cells. A, Phase micrograph of $\mathrm{C}$-cells culture on fibronectin and laminin substratum treated with NGF for $6 \mathrm{~d}$. Indicated neurite extends approximately $550 \mu \mathrm{m}$. $B$, Phase micrograph of $\mathrm{C}$-cell culture on fibronectin and laminin substratum treated with NGF for $6 \mathrm{~d}$. $C$, A fluorescence micrograph of the same cell shown in $B$, immunostained with antiserum against CT. $D$, Brightfield micrograph of HRP-DAB stained C-cell culture on PYS matrix treated with NGF for $5 \mathrm{~d}$, immunostained with antiserum against CGRP. Background nuclear staining of fibroblasts can be seen. $E$, Bright-field micrograph of HRP-DAB stained C-cell culture on PYS matrix treated with NGF for $5 \mathrm{~d}$, immunostained with a monoclonal antibody against $160 \mathrm{kDa}$ neurofilament (NF-M). Neurites are indicated by arrows. Magnification bars, $50 \mu \mathrm{m}$.

contained varicosities and growth cone-like structures. Identification of the C-cells was confirmed by CT immunostaining (Fig. $2 B, C)$. Neurites were seen on cells from both fibronectin- and PYS matrix-coated plates, although the PYS matrix-coated dishes promoted extension from a greater number of cells and more extensive arborization. On the fibronectin-coated dishes, the neurites were generally $40-80 \mu \mathrm{m}$ in length, although some neurites extended up to $550 \mu \mathrm{m}$ (Fig. $2 A$ ).

In addition to neurite extension, we also found that NGF treated C-cells displayed neurofilament immunoreactivity using a monoclonal antibody against the $160 \mathrm{kDa}$ neurofilament protein (NF-M) (Fig. 2E). To further examine neurofilament expression in thyroid C-cells, double staining of NGF treated and control C-cell cultures with antisera to calcitonin and neurofilament was performed. As expected, most thyroid C-cells did not express 

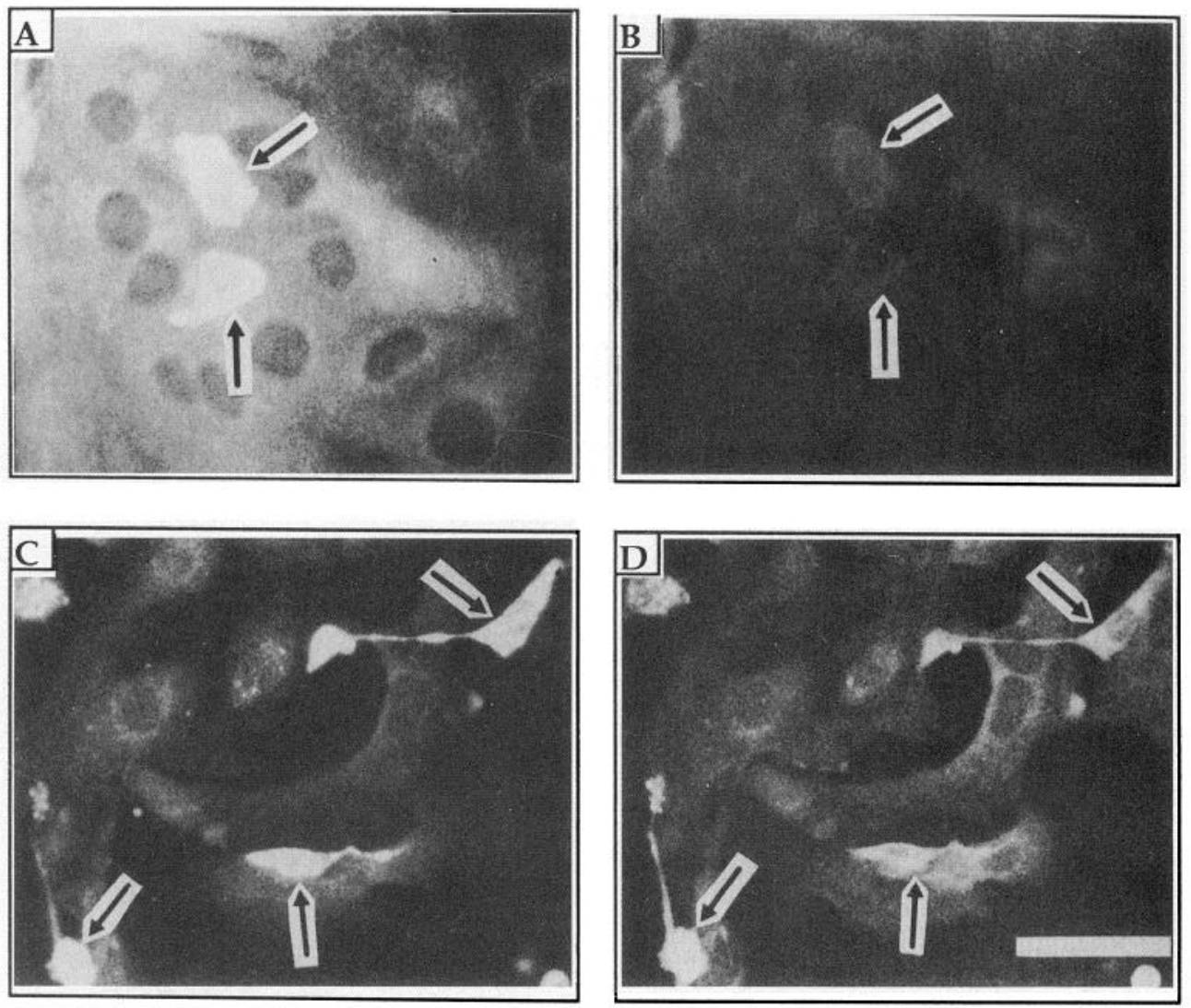

E.
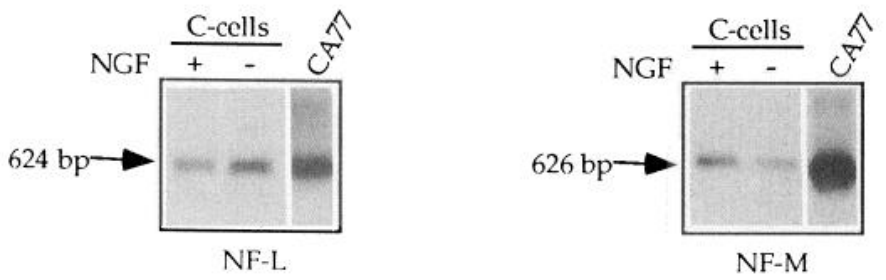

Figure 3. Neurofilament expression in C-cell cultures. $A-D$, Thyroid primary cultures on fibronectin and laminin substratum were double immunostained using antisera against calcitonin (CT) (left panels) and the $160 \mathrm{kDa}$ neurofilament (NF-M) (right panels). The cultures were untreated control $(A, B)$, or treated with NGF and basic FGF ( $C$, $D)$. Staining with CT was used to identify C cells, indicated with arrows. CT and NF-M were detected with FITC and rhodamine conjugated secondary antibodies, respectively. $E$, Total RNA was isolated from control and NGF (5 d) treated primary cultures on fibronectin and laminin. The RNA was reverse transcribed and PCR amplified using neurofilament NF-L or NF-M specific primers. CA77 RNA was included as a positive control. A Southern blot of the RT-PCR products is shown. Size of bands detected are as indicated. Exposure times were $25 \mathrm{~min}$ and $1.5 \mathrm{~min}$ for NF-L and NF-M, respectively. Magnification bars, $50 \mu \mathrm{m}$. abundant neurofilament immunoreactive material (Fig. 3A,B). This agrees with the lack of neurofilaments in adult sheep thyroid C-cells (Barasch et al., 1987a). Likewise, we did not detect any neurofilament immunopositive cells in sections of rat thyroid (data not shown). However, occasionally a C-cell could be detected that showed neurofilament immunoreactivity after several days in culture, indicating that some limited neurofilament expression could occur in culture. Treatment with NGF for $5 \mathrm{~d}$ induced the $160 \mathrm{kDa}$ neurofilament in nearly all of the $\mathrm{C}$-cells as measured by immunohistochemistry (Fig. $3 C, D$ ). While there was some variation in the intensity of staining, greater than $85 \%$ of the C-cells were immunopositive. Since studies on the sympathoadrenal neural crest have shown that FGF treatment acts sequentially with NGF (Stemple et al., 1988), we also asked whether basic FGF augmented the NGF induction of neurofilaments. Treatment with FGF alone produced no increase in immunostaining over control; and FGF in combination with NGF caused little or no increase in neurofilament immunostaining over treatment with NGF alone (data not shown).

The expression of neurofilaments shown by immunostaining was confirmed by identification of neurofilament RNA in the thyroid primary cultures. We chose to characterize both the 68 $\mathrm{kDa}$, and $160 \mathrm{kDa}$ neurofilament (NF-L and NF-M, respectively) RNAs so as to document the presence of an additional type of neurofilament in the C-cells. Sets of oligonucleotide primers complementary to the NF-L or NF-M coding region were used for reverse transcription and polymerase chain reaction (RTPCR) amplification of primary culture RNA. The RT-PCR products were resolved by agarose gel electrophoresis and analyzed by Southern blot hybridizations to confirm the identity of the amplification products. Single PCR amplification products of the expected size (NF-L, 624 bp; NF-M, 626 bp) were detected (Fig. $3 E$ ). While NF-L and NF-M RNAs were detected in both NGF and non-NGF treated cultures, the RT-PCR reaction was not performed as a quantitative assay and hence NGF might have induced neurofilament RNA as well as immunoreactivity. Since a small fraction of control cells extended neurites and displayed NF immunoreactivity, and since RT-PCR is more sensitive than immunostaining; it is not surprising that control cultures yielded NF RT-PCR products. In this regard, it should be noted that in some cultures, NF-L RT-PCR products from control cultures, unlike those from NGF treated cultures, required two rounds of 
Figure 4. MASH-1 expression in thyroid C-cells. A, Rat thyroid slices were stained with an antibody against MASH-1 with Cy3-conjugated secondary antibodies. A confocal fluorescence micrograph is shown. Several C-cells are indicated by arrows. $B$, Rat thyroid slice stained with antiserum against calcitonin and detected as in $A . C$, Immunostaining of CA77 cells with an antibody against MASH-1 detected with FITC conjugated secondary antibody. Arrows indicate nuclear staining. A negative photographic image is shown. $D$, Total RNA was isolated from the rat tissues and cell lines. RNA from $\mathrm{C}$-cell cultures on fibronectin and laminin was isolated after $2 \mathrm{~d}$ in culture. The RNA was reverse transcribed and PCR amplified using product specific primers. MASH-1, Mammalian achaete-scute homolog-1; $C T$, calcitonin; $A C T, \beta$-actin. Predicted sizes were MASH-1, 295 bp; CT, 335 bp; ACT, 764 bp. An ethidium bromide stained agarose gel of the RT-PCR products is shown. The identity of the MASH-1 RT-PCR product was confirmed by partial sequence determination. Magnification bars, $50 \mu \mathrm{m}(A-C)$.
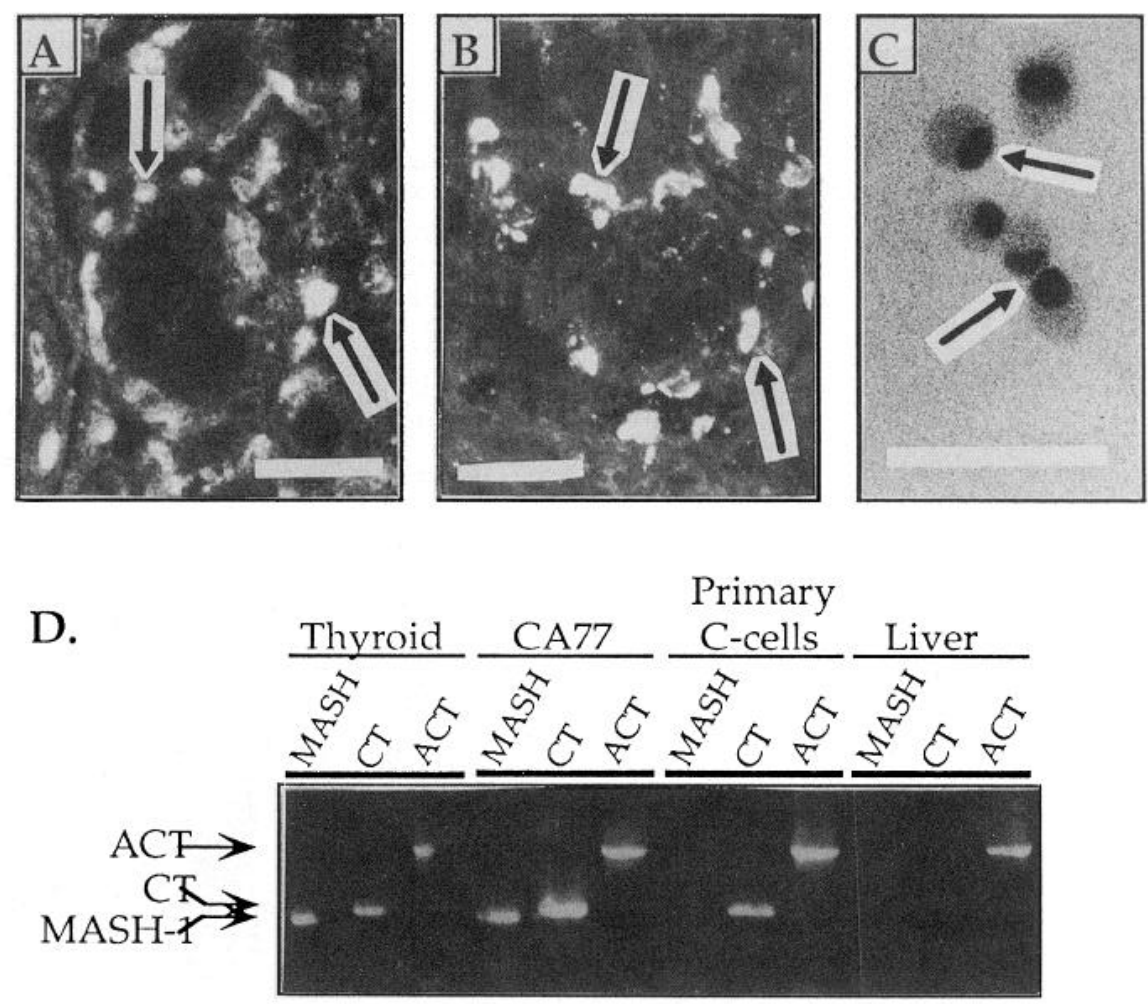

amplification for detection. For comparison NF-L and NF-M were amplified from the CA77 cells, which we have previously shown to express NF-L and NF-M (Russo et al., 1992) (Fig. $3 E$ ). As controls, $\beta$-actin and CT were amplified from both the control and NGF treated primary cultures to confirm the RNA integrity and the presence of C-cell RNA. The expected size products were observed for both these controls, $764 \mathrm{bp}$ for $\beta$-actin and 335 bp for CT.

\section{Expression of MASH-1 and B2 sympathoadrenal markers in C-cells}

The MASH-1 protein is a basic helix-loop-helix transcription factor characteristic of neural crest sympathoadrenal progenitors (Johnson et al., 1990). Within this cellular population, MASH-1 is expressed before, but not after, neuronal differentiation (Johnson et al., 1990; Lo et al., 1991; Guillemot and Joyner, 1993). In addition, the presence of MASH-1 RNA has been reported in a C-cell line (Johnson et al. 1990). Since MASH-1 is present in sympathoadrenal progenitors and C-cell lines, we have hypothesized that it may also be present in normal C-cells before, but not after, neuronal differentiation.

To determine if MASH-1 protein was present in C-cells, we immunostained thyroid sections with an antiserum to MASH-1. As determined by confocal microscopy, C-cells expressed apparently nuclear MASH-1 immunoreactivity (Fig. 4A). For comparison, we also stained a comparable thyroid section with antiserum to calcitonin (Fig. 4B). MASH-1 immunoreactivity was also nuclear in CA77 cells (Fig. $4 C$ ). In contrast, we were unable to detect MASH-1 immunoreactivity in C-cell cultures (data not shown). We also examined MASH-1 expression in thyroid and cultured C-cells by RT-PCR (Fig. 4D). MASH-1 was clearly detectable in RNA isolated from juvenile rat thyroids. It was also detected immediately after dissection and dispersion of the thyroid. In contrast, MASH-1 RNA was undetectable in C-cells cultured for one day or longer (Fig. $4 D$ ). The same result was observed in the presence or absence of NGF. However, as indicated by the presence of NF mRNA in control cultures, untreated C-cells display features consistent with the initial steps of neuronal differentiation simply by being placed in culture. As controls for the RT-PCR, we examined the CA77 C-cell line. Consistent with the above mentioned immunostaining and the results of Johnson et al. (1990), showing MASH-1 RNA in another C-cell line; MASH-1 was detected in CA77 RNA. Also as expected, MASH-1 was not detected in either rat liver or HeLa RNA. As a control for the presence of C-cell RNA in the thyroid cultures, CT was amplifed. The expected product (335 bp) was detected from thyroid, CA77, and C-cell RNA but not from liver or HeLa. To control for RNA integrity, $\beta$-actin was amplified from all RNA samples. The expected 764 bp product was detected in all cases (Fig. 4D).

The expression of MASH-1, and the similar regulation of neuronal differentiation of C-cells and chromaffin cells by NGF, suggested that $\mathrm{C}$-cells might arise from a sympathoadrenal progenitor. To further test this prediction, we used the B2 antibody as a specific marker of sympathoadrenal progenitors. The B2 antibody recognizes a cell-surface marker previously reported only on embryonic cells derived from the sympathoadrenal lineage (Anderson and Axel, 1986; Carnahan et al., 1991). We observed B2 immunoreactivity in C-cells cultured for one day as well as in thyroid sections (Fig. 5A). B2 immunoreactivity, however, was not clearly detectable in C-cells cultured for $5 \mathrm{~d}$, regardless of NGF treatment. B2 immunostaining was also detected on the cell surface in the CA77 C-cell line (Fig. 5B). As a control, we did not observe immunostaining of Rat 1 fibroblasts.

\section{Production of 5-HT in cultured C-cells}

The presence of 5-HT in cultured C-cells was determined using a polyclonal antiserum. Virtually all C-cells displayed 5-HT im- 

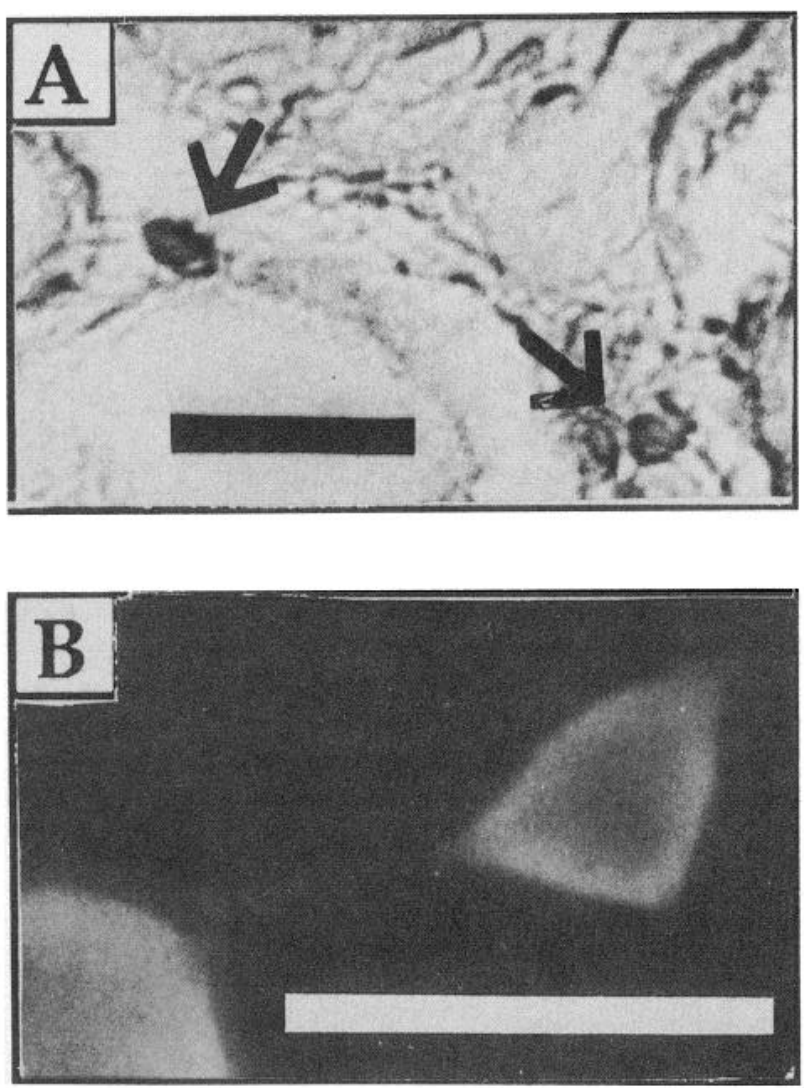

Figure 5. B2 expression in thyroid C-cells. A, Rat thyroid slice stained with $\mathrm{B} 2 \mathrm{~B} 1$ antibody. HRP-conjugated secondary was used to detect B2B1. A DAB stained bright-field micrograph is shown. Arrows indicate C-cells. B, Fluorescence micrograph of CA77 cell stained with B2B1 antibody. Primary antibody was detected using FITC conjugated secondary antibody. Magnification bars, $50 \mu \mathrm{m}$.

munoreactivity. NGF treatment did not seem to enhance staining, but cells with NGF induced neurites displayed 5-HT immunoreactivity within these processes (Fig. $6 A, B$ ). Although it was impractical to determine 5 -HT levels in primary C-cell cultures, CA77 cells store about 6 pmol of 5-HT per $10^{6}$ cells, as determined using HPLC with electrochemical detection (Tamir et al., 1989). Basal release rate was $1 \mathrm{pmol} / 10^{6}$ cells in $10 \mathrm{~min}$. Treatment with $\mathrm{Ca}^{2+}(5 \mathrm{~mm})$ increased release to $2 \mathrm{pmol} / 10^{6}$ cells in $10 \mathrm{~min}$.

The production of 5-HT requires expression of tryptophan hydroxylase (TPH), the rate limiting enzyme in the synthesis of 5 -HT. This is a key feature of serotonergic neurons, and is not found in many cells that store 5-HT, such as platelets. In order to examine the presence of TPH RNA in C-cell cultures, we used RT-PCR. TPH RNA was detected in both NGF and control cultures (Fig. 6C). Partial sequence determination of the PCR product was identical to the neuronal TPH cDNA (Kim et al., 1991).

\section{Expression of 5-HT $T_{I B}$ receptor, and 5-HT transporter mRNAs in cultured $\mathrm{C}$-cells}

In order to function as serotonergic neurons, neuronally differentiated C-cells should display several properties. They should be capable of releasing 5-HT stored in vesicles, activate tryptophan hydroxylase, have a mechanism for sensing 5-HT (i.e., an autoreceptor), and be able to remove it from the environment (i.e., a 5-HT transporter). Some these issues have been resolved by Tamir et al. (1989), who examined a human medullary thyroid carcinoma cell line (TT). We have asked whether these properties are present in rat C-cells cultured with or without NGF.

Serotonergic neurons sense the levels of extracellular 5-HT via autoreceptors. In rodent dorsal raphe, two members of the $5-\mathrm{HT}_{1}$ family are believed to function as autoreceptors, 5- $\mathrm{HT}_{1 \mathrm{~A}}$ and 5- $\mathrm{HT}_{1 \mathrm{~B}}$ receptors (Voight et al., 1991; Boess and Martin,

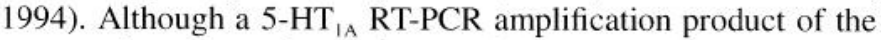
correct size was produced from rat brain RNA, no product was detectable in RNA from cultured rat C-cells or thyroid (data not shown). However, in both NGF and non-NGF treated C-cell cultures, amplification using $5-\mathrm{HT}_{1 \mathrm{~B}}$ primers yielded a single band of the predicted size ( $303 \mathrm{bp})$. The identify of this band was determined by Southern analysis with confirmation by partial sequence determination (Fig. 6D).

Serotonergic neurons also possess a mechanism for removing transmitter from the extracellular environment, via a neuronal 5-HT transporter. We have used RT-PCR to detect the presence of this mRNA. In order to reliably amplify 5-HT transporter message by RT-PCR, it was necessary to use a semi-nested PCR. The use of the semi-nested RT-PCR technique was necessary to clearly detect products from rat brain, as well as the C-cells. With C-cell RNA, this procedure occasionally yielded multiple products, of which the predominant one in RNA from NGF treated cultures was $567 \mathrm{bp}$, the predicted size for the 5-HT transporter RT-PCR product (Blakely et al., 1991). The identity of the 567 bp band was confirmed by Southern analysis and partial sequence determination (Fig. 6E). Although the RT-PCR reactions were not set up as quantitative measurements, transporter message was easily detected in NGF treated cultures, while it was barely detectable even by Southern hybridization in control cultures (Fig. 6E). This semiquantitative finding indicates that NGF increases 5-HT transporter RNA levels.

C-Cell cultures are a mixture of cell types. In order to confirm that C-cells were responsible for the above findings, rather than other cell types; we examined the presence of serotonergic markers in the CA77 C-cell line. Amplification of CA77 total RNA demonstrated the presence of $5-\mathrm{HT}_{1 \mathrm{~B}}$ and $5-\mathrm{HT}$ transporter RNAs (Fig. 6D,E), supporting the conclusion that C-cells were the source of these RNAs in the cultures. In addition, 5-HT $\mathrm{TA}_{\mathrm{A}}$ RNA was undetectable in CA77 cells, a result identical to that obtained with C-cell cultures.

\section{NGF induction of 5-HT transporter activity}

In order to functionally assess the presence and NGF induction of transporter RNA in NGF treated C-cells, we pharmacologically examined the uptake of 5-HT. The 5-HT transporter is a sodium dependent 5 -HT transporter that can be inhibited by a number of tricyclic and heterocyclic antidepressant agents (Blakely et al., 1991). 5-HT transport may be selectively blocked using sertraline, a napthylamine antidepressant with essentially no effects on the uptake of other biogenic amines (Koe et al., 1983). We examined the uptake of ${ }^{3} \mathrm{H}$-labeled 5-HT into C-cell cultures in the presence and absence of sertraline $(5 \mu \mathrm{M})$. In control cultures, sertraline had almost no effect on uptake, indicating very low or non-existent functional neuronal 5-HT transporter activity (Fig. 7A). In NGF treated C-cells, however, sertraline repressed 5-HT uptake to about $55 \%$ of uptake in the absence of the inhibitor (Fig. $7 B$ ). Since the C-cells were not 
Figure 6. 5-HT, tryptophan hydroxylase, 5- $\mathrm{HT}_{1 \mathrm{~B}}$ autoreceptor and 5-HT transporter RNA in C-cells. A, Brightfield micrograph of HRP-DAB stained C-cell culture on PYS matrix treated with NGF for $5 \mathrm{~d}$, immunostained with antiserum against 5-HT. Neurites are indicted by arrows. Background nucleolar staining of fibroblast can be seen. $B$, Bright-field micrograph of HRP-DAB stained control C-cell culture on PYS matrix, immunostained with antiserum against 5-HT. $C$, Total RNA was isolated from control and NGF $(5 \mathrm{~d})$ treated primary cultures. The RNA was reverse transcribed and PCR amplified using TPH specific primers. A Southern blot of the RT-PCR products is shown with product size as indicated. Exposure times were $5 \mathrm{~min}$ for $\mathrm{C}$-cell cultures and thyroid, and $2 \mathrm{~min}$ for CA77. $D$, Southern blot of total RNA was prepared as in $C$, reverse transcribed, and PCR amplified using 5- $\mathrm{HT}_{1 \mathrm{~B}}$ specific primers. Exposure time was $30 \mathrm{~min}(5$ min for CA77). (E) Southern blot of total RNA was prepared as in $C$, reverse transcribed, and PCR amplified using 5-HT transporter specific primers. Exposure time was $1 \mathrm{hr}$ (with enhancer screen) for primary RNA and $5 \mathrm{~min}$ for CA77 RNA. In $C-E$, CA77 RNA was included for comparison and to confirm that products were derived from $\mathrm{C}$-cell RNA. Magnification bars, $50 \mu \mathrm{m}$.
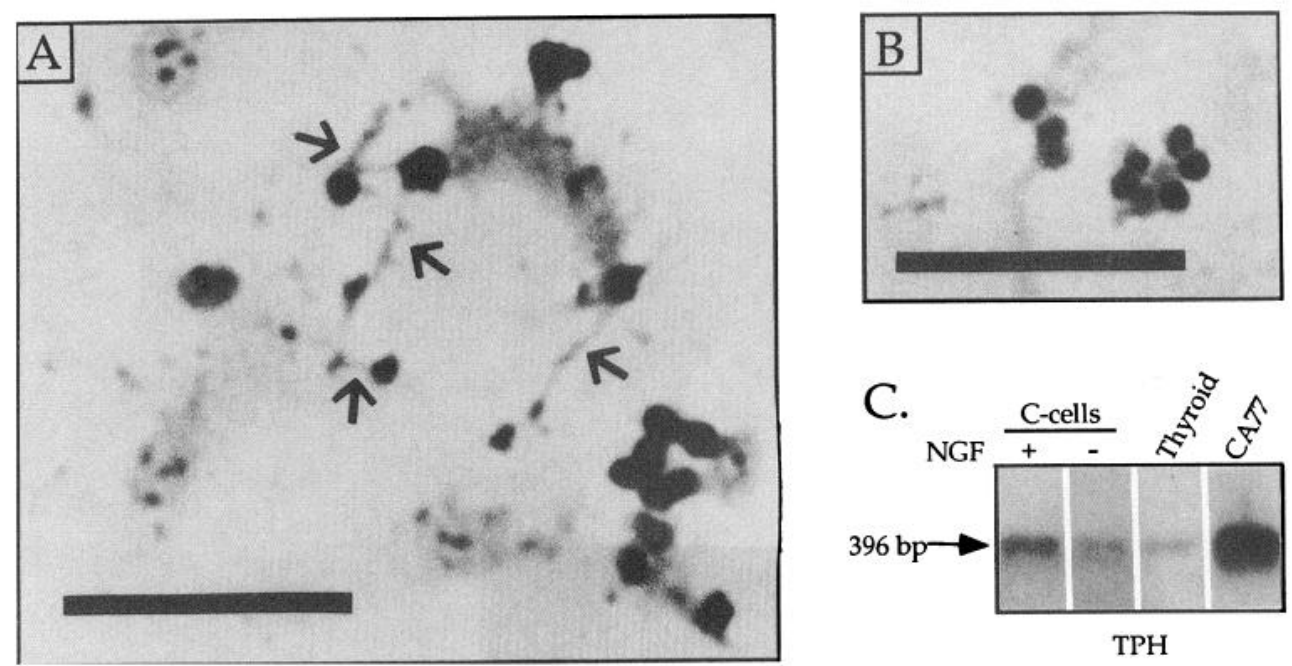

TPH

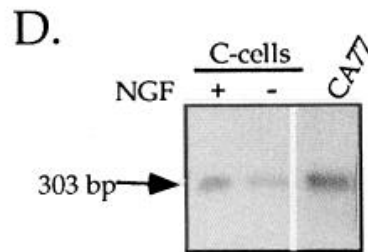

$5-\mathrm{HT}_{1 \mathrm{~B}}$
E.

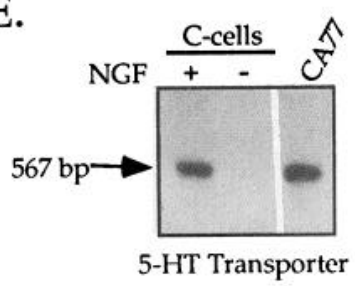

pure, the remaining nonsertraline inhibitable uptake was most likely due to nonspecific transport by contaminating fibroblasts.

In order to confirm that $\mathrm{C}$-cells were responsible for the sertraline inhibitable uptake of 5-HT, the experiment was repeated using the CA77 cell line. In the cell line, sertraline reduced uptake of 5 -HT to about $8 \%$ of uptake in the absence of the inhibitor (Fig. $7 \mathrm{C}$ ). Similar results were obtained with CA77 cells using the 5-HT uptake inhibitor fluoxetine $(5 \mu \mathrm{M})$. These results demonstrate that NGF is increasing neuronal 5-HT transporter activity in C-cells, and are consistent with the apparent increase in transporter RNA levels following NGF treatment.

\section{Discussion}

One of the most distinctive features of neural crest cells is their phenotypic plasticity in response to environmental cues. Neuronal-endocrine plasticity in mature thyroid $\mathrm{C}$-cells raises the prospect that $\mathrm{C}$-cells arise from a neurogenic progenitor, analogous to the endocrine chromaffin cells (Barasch et al., 1987a; Tamir et al., 1989; Anderson, 1993). The results of this study strengthen this model and furthermore suggest that thyroid C-cells arise from a late and reversible commitment of a sympathoadrenal progenitor cell (Fig. 8). This prediction is based on the following rationale. (1) Expression of the MASH-1 transcription factor (Johnson et al., 1990; Carnahan et al., 1991; this report), and the B2 sympathoadrenal marker (Carnahan et al., 1991; this report) as indicators of sympathoadrenal lineage. (2) The shared endocrine-neuronal transdifferentiation induced by NGF with sympathoadrenal-derived chromaffin cells (Unsicker et al., 1978; Doupe et al., 1985; Barasch et al., 1987a; this report). (3) The shared origin, migration, and pattern of gene expression with enteric neurons. Most striking is the expression of serotonergic features, including expression of tryptophan hy- droxylase, production of 5-HT from tryptophan, 5-HT binding proteins, 5-HT autoreceptors, and a neuronal 5-HT transporter (Nunez and Gershon, 1972; Barasch et al., 1987b; this report). While we have not formally established a lineage relationship, taken together these observations strongly support the hypothesis that C-cells are vagal crest derivatives from a sympathoadrenal progenitor.

An indication of neuronal potential in cultured C-cells is the expression of MASH-1. MASH-1 is a transcription factor that has been shown to be present in neuronal precursors, including sympathoadrenal progenitors, but not in neurons after differentiation (Johnson et al., 1990; Lo et al., 1991; Guillemot and Joyner, 1993). Mice homozygous for MASH-1 mutations are nonviable and show severe defects in autonomic ganglia, in which neuronal precursors are present but neuronal differentiation is arrested (Guillemot et al., 1993). We have shown that MASH-1 RNA is present in juvenile rat thyroid. At present the only other example of MASH-1 expression in the postnatal animal is in the olfactory neuroblasts (Guillemot and Joyner, 1993). Detection of MASH-1 in C-cells suggests that C-cells retain the neurogenic potential of sympathoadrenal progenitors. Furthermore, the subsequent loss of MASH-1 in the primary cultures is consistent with neuronal differentiation, since even control cultures begin to express neurofilament RNA. These results suggest that some characteristics of the thyroid environment may repress neuronal features in C-cells. Supporting this possibility, Jacobs-Cohen et al. (1994) have suggested that triiodothyronine may repress the development of a neuronal phenotype in C-cells. Similarly, dexamethasone can partially repress neuronal features of the CA77 cell line (Russo et al., 1992). It is also possible that factors present on the surfaces of some 
A.

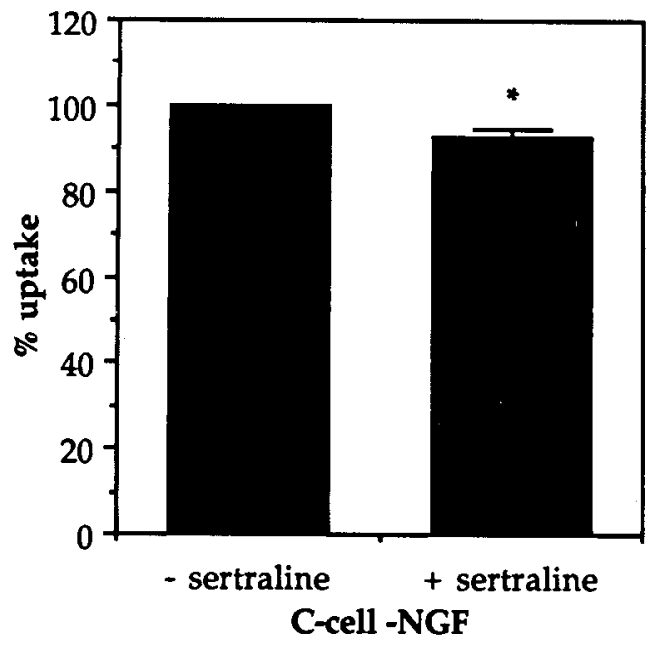

C.

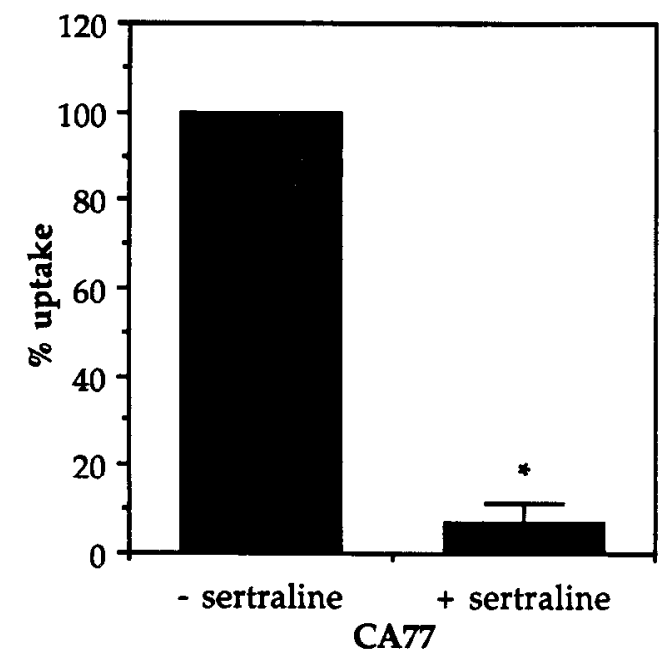

B.

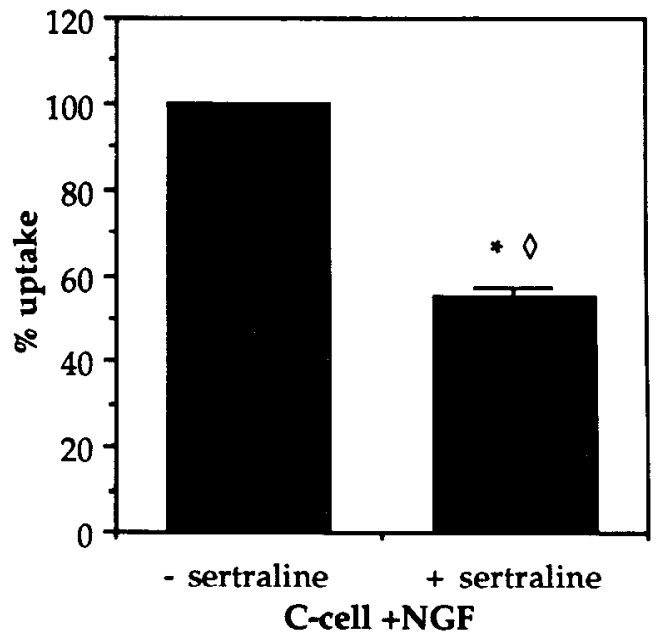

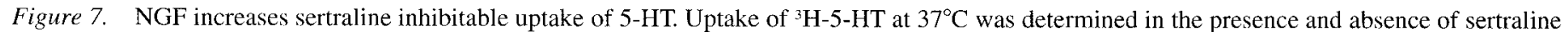

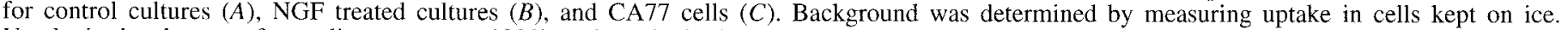

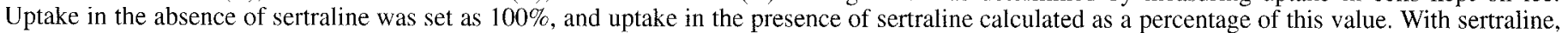

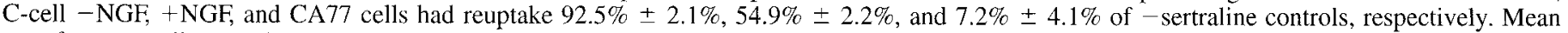

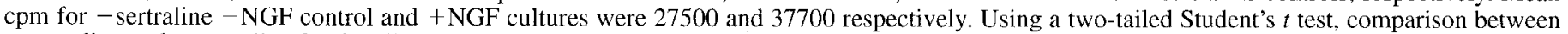

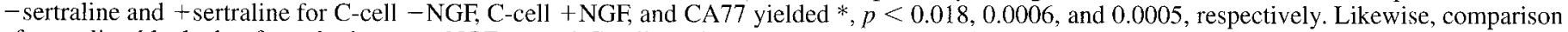
of sertraline blockade of uptake between NGF treated C-cells and untreated cells yielded $\diamond, p<0.0016$.

neighboring cells may be involved in repression of neuronal phenotypes. We have seen that contact with non-C-cells from the thyroid gland appears to inhibit neurite production in C-cell cultures (unpublished data). Therefore, it appears that C-cell progenitors may be induced to assume an endocrine phenotype by the thyroid environment, a situation analogous to the sympathoadrenal derived chromaffin cells and the adrenal environment.

In addition to MASH-1, the expression of the sympathoadrenal specific B2 antigen also suggests that C-cells derive from, and retain properties of sympathoadrenal progenitors. This marker is specifically expressed transiently in the sympathoadrenal derived cells, including the prechromaffin cells and enteric neuroblasts (Anderson and Axel, 1986; Carnahan et al., 1991). We have demonstrated that B2 antigen is present on C-cells in vivo, as well as after one day of culture, but that it is consid- erably reduced after $5 \mathrm{~d}$. While expression of these markers in C-cells is by itself not conclusive evidence of a lineage, it strongly supports the view that $\mathrm{C}$-cells derive from a sympathoadrenal progenitor.

In cultured C-cells, NGF induces neuronal transdifferentiation. However, it is not clear whether NGF is responsible in vivo for neuronal differentiation of vagal sympathoadrenal progenitors. The possibility that NGF may normally contribute to C-cell function has been suggested by the observation of hypothyroidism in rats administered NGF antiserum (Levi-Montalcini, 1982), as discussed by Barasch et al. (1987a). It is clear that NGF is not the sole determinant of the enteric neuronal phenotype (Baetge et al., 1990; Gershon et al., 1993; Schuchardt et al., 1994). Since NGF acts through a receptor tyrosine kinase, it is also notable that the ret receptor tyrosine kinase has been genetically linked to C-cell tumors (Santoro et al., 1990). This 


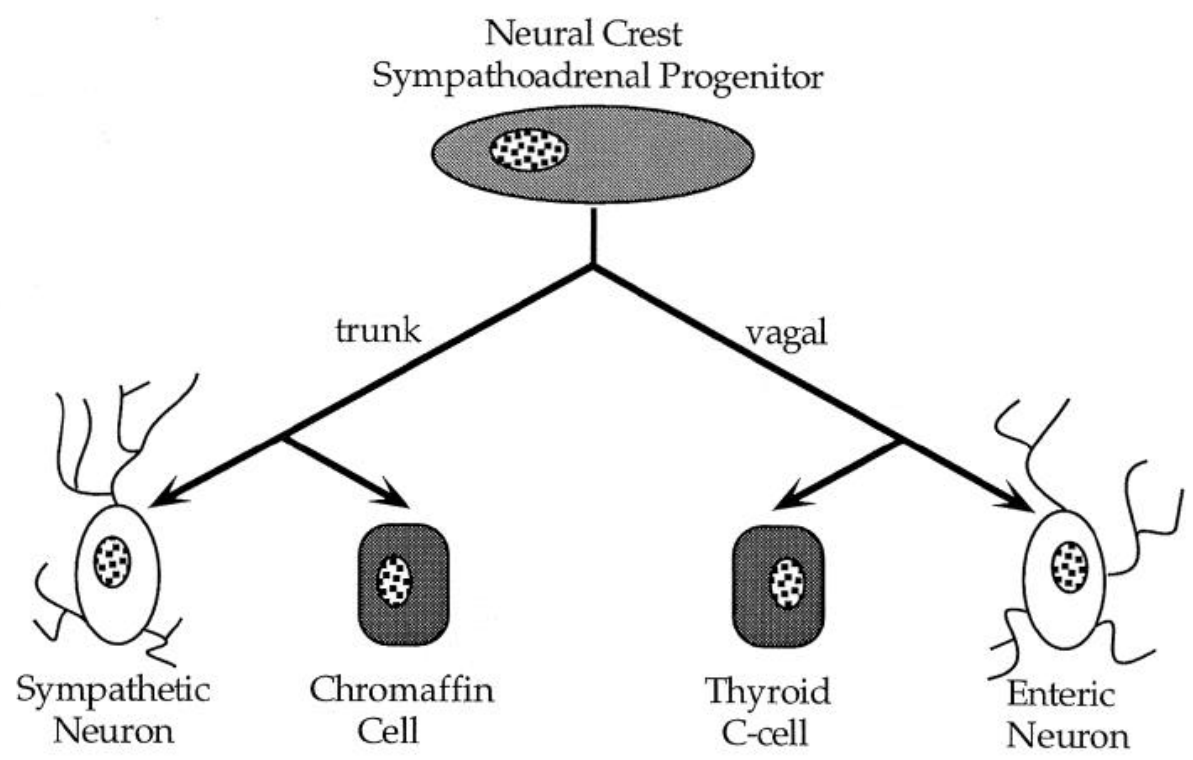

Figure 8. Model of thyroid C-cell derivation from a sympathoadrenal progenitor. The sympathoadrenal progenitor in the vagal neural crest is proposed to give rise to thyroid $\mathrm{C}$-cells based on their expression of sympathoadrenal markers (MASH-1 and B2), NGF induced endocrine-neuronal transdifferentiation, and expression of a serotonergic phenotype similar to enteric neurons. Similar neuronal phenotypes are also seen in C-cell carcinomas (e.g., CA77 cells). Trunk sympathoadrenal lineage and chromaffin cell transdifferentiation have been described (LeDouarin, 1982; Anderson, 1993). raises the possibility that ret activity may also be responsible for the neuronal properties common in cell lines derived from these tumors. Consistent with this predicted role of ret in neuronal differentiation of the vagal neural crest is the failure of the enteric nervous system to develop in mice lacking the ret gene (Schuchardt et al., 1994). While enteric neuroblasts form and migrate in these mice, the cells fail to fully differentiate into mature neurons. Consequently, NGF actions on the C-cells may be mimicking the activity of the ret tyrosine kinase.

Finally, we have demonstrated that cultured C-cells have properties similar to serotonergic neurons. Cultures display 5-HT immunoreactivity and express tryptophan hydroxylase, the rate limiting enzyme in 5-HT biosynthesis. Partial sequencing of a TPH RT-PCR product did not reveal any differences from the neuronal TPH cDNA. In addition, northern analysis of CA77 RNA demonstrated the existence of both $1.8 \mathrm{~kb}$ and $4.0 \mathrm{~kb}$ TPH species (Clark et al., 1995), as identified in the brain by Darmon et al. (1988). This demonstrates that TPH transcripts in C-cells are similar if not identical to that found in the CNS. Furthermore, we have detected the presence of $5-\mathrm{HT}_{1 \mathrm{~B}}$ axonic autoreceptor and 5-HT transporter RNA in C-cells. The transporter activity is especially responsive to NGF treatment. NGF effects are primarily transduced via the trkA receptor tyrosine kinase, which results in activation of MAP-kinase (Chao, 1992). However, NGF treatment of PC12 cells has also been shown to result in phosphorylation of cyclic AMP responsive element binding protein (CREB), with an increase in c-fos transcription (Ginty et al., 1994). Increases in intracellular cAMP have previously been reported to increase 5-HT transporter activity and mRNA levels in a human placental choriocarcinoma cell line (Cool et al., 1991; Ramamoorthy et al., 1993), while activation of protein kinase $\mathrm{C}$ reduces 5-HT transport in isolated platelets (Anderson and Horne, 1992). Our results show that NGF, similar to cAMP, is also capable of increasing transporter activity and mRNA levels. The C-cell system should prove useful not only in studying the effect of various second messenger systems on 5-HT transporter activity, but also possible interactions between neurotrophin and cAMP mediated signal transduction.

The significance of our results showing that NGF induces a serotonergic neuronal phenotype in C-cells lies in the potential use of C-cells as a serotonergic model system. Many previous studies on serotonergic neurons have used the platelet as a model system, because it can take up and store 5-HT (Da Prada and Pletscher, 1968), despite numerous differences between these cells and serotonergic neurons, as reviewed by Gershon and Tamir (1984). In contrast, C-cells, as discussed above, do share many properties with serotonergic neurons. Of particular interest are the features we have examined in this report, the expression of tryptophan hydroxylase and 5- $\mathrm{HT}_{1 \mathrm{~B}}$ autoreceptor RNA, and 5-HT transporter RNA and activity. Disregulation of serotonergic systems is believed to be involved with the pathogenesis of a number of psychiatric disorders, particularly major depressive disorder and obsessive-compulsive disorder (Azmitia and Whitaker-Azmitia, 1991). The first-line drug treatments for these disorders are 5-HT reuptake inhibitors, including sertraline, which act on the neuronal 5-HT transporter (Grimsley and Jann, 1992). In addition, long term administration of these drugs produce downregulation of 5- $\mathrm{HT}_{1 \mathrm{~B}}$ autoreceptor activity (Chaput et al., 1991). Since C-cells in culture can express both the 5-HT ${ }_{1 B}$ autoreceptor and 5-HT transporter, they offer an opportunity to study molecular interactions between the blockade of transporter function with uptake inhibitors and autoreceptor activity. More importantly, the effect of modulating these systems upon TPH transcription and enzymatic activity may be easily examined. C-cell cultures may also provide a useful complement to a recently reported cell line derived from immortalized embryonic raphe neurons (White et al., 1994), for examining the common and distinguishing features between central and peripheral serotonergic neurons. Therefore, C-cells cultures offer an opportunity to study the molecular biology of 5-HT biosynthesis, autoreceptors, and transport in a neuronal model system amenable to in vitro manipulation.

\section{References}

Anderson DJ (1993) Molecular control of cell fate in the neural crest: the sympathoadrenal lineage. Annu Rev Neurosci 16:129-158.

Anderson DJ, Axel R (1986) A bipotential neuroendocrine precursor whose choice of cell fate is determined by NGF and glucocorticoids. Cell 47:1079-1090.

Anderson GM, Horne WC (1992) Activators of protein kinase C decrease 5-HT transport in human platelets. Biochem Biophys Acta 1137:331-337.

Azmitia EC, Whitaker-Azmitia PM (1991) Awakening the sleeping 
giant: anatomy and plasticity of the brain serotonergic system. J Clin Psychiatry 52(Suppl 12):4-16.

Baetge G, Pintar JE, Gershon MD (1990) Transiently catecholaminergic (TC) cells in the bowel of the fetal rat: precursors of noncatecholaminergic enteric neurons. Dev Biol 141:353-380.

Barasch JM, Mackey H, Tamir H, Nunez EA, Gershon MD (1987a) Induction of a ncural phenotype in a serotonergic endocrine cell derived from the neural crest. J Neurosci 7:2874-2883.

Barasch JM, Tamir H, Nunez EA, Gershon MD (1987b) Serotoninstoring secretory granules from thyroid parafollicular cells. J Neurosci 7:4017-4033.

Blakely RD, Berson HE, Fremeau RT Jr, Caron MG, Peek MM, Prince HK, Bradley CC (1991) Cloning and expression of a functional serotonin transporter from rat brain. Nature 354:66-70.

Boess FG, Martin II, (1994) Molecular hiology of 5-HT receptors. Neuropharmacology 33:275-317.

Carnahan JF, Anderson DJ, Patterson PH (1991) Evidence that enteric neurons may derive from the sympathoadrenal lineage. Dev Biol 148: $552-561$

Chaput Y, de Montigny C, Blier P (1991) Presynaptic and postsynaptic modifications of the serotonin system by long-term administration of antidepressant treatments: an in vivo electrophysiologic study in the rat. Neuropsychopharmacology 5:219-229.

Chao MV (1992) Neurotrophin receptors: a window into neuronal differentation. Neuron 9:583-593.

Chou DKH. Dodd J, Jessell TM, Costello CE, Jungalwala FB (1989) Identification of $\alpha$-galactose ( $\alpha$-fucose)-asialo $G_{\mathrm{m} 1}$ glycolipid expressed by subsets of rat dorsal root ganglion neurons. J Biol Chem 264:3409-3415

Ciment G, Weston JA (1983) Enteric neurogenesis by neural crestderived branchial arch mesenchymal cells. Nature 305:424-427.

Ciment G, Weston JA (1985) Segregation of developmental abilities in neural-crest-derived cells: identification of partially restricted intermediate cell types in the branchial arches of avian embryos. Dev Biol 111:73-83.

Clark MS, Johnson W, Russo AF (1994) Dexamethasone repression of tryptophan hydroxylase mRNA levels in the CA77 cell line. Soc Neurosci Abstr 20:289.

Clark MS, Lanigan TM, Russo AF (1995) Serotonergic neuronal properties in C-cell lines. Methods [companion to Methods Enzymol] 7: 253-261

Cool DR, Leiback FH, Bhalla VK, Mahesh VB, Ganapathy V (1991) Expression and cyclic AMP dependent regulation of a high affinity serotonin transporter in the human placental choriocarcinoma cell line (JAR). J Biol Chem 266:15750-15757.

Crawford JA, Mutchler KJ, Sullivan BE, Lanigan IM, Clark MS, Russo AF (1993) Neural expression of a novel alternatively spliced and polyadenylated Gsa transcript. J Biol Chem 268:9879-9885.

Da Prada M, Pletscher A (1968) Isolation of 5-hydroxytryptamine organelles of rabbit blood platelets: physiological properties and drug induced changes. Br J Pharmacol 34:591-597.

Darmon MC, Guibert B, Leviel V, Ehret M, Maitre M, Mallet J (1988) Sequence of two mRNAs encoding active rat tryptophan hydroxylase. J Neurochem 51:312-316.

Dodd J, Jessell TM (1985) Lactoseries carbohydrates specify subsets of dorsal root ganglion neurons projecting to the superficial dorsal horn of rat spinal cord. J Neurosci 5:3278-3294.

Doupe AJ, Landis SC, Patterson PH (1985) Environmental influences in the development of neural crest derivatives: glucocorticoids, growth factors, and chromaffin cell plasticity. J Neurosci 5:21192142.

Gard DL, Lazarides Flias (1980) The synthesis and distribution of desmin and vimentin during myogenesis in vitro. Cell 19:263-275.

Gershon MD, Tamir H (1984) Serotonectin and the family of proteins that bind serotonin. Biochem Pharmacol 33:3115-3118.

Gershon MD, Chalazonitis A, Rothman TP (1993) From neural crest to bowel: development of the enteric nervous system. J Neurobiology $24: 199-214$

Ginty DD, Bonni A, Greenberg ME (1994) Nerve growth factor activates a ras-dependent protein kinase that stimulates $c$-fos transcription via phosphorylation of CREB. Cell 77:713-725.

Grimsley SR, Jann MW (1992) Paroxetine, sertraline, and fluvoxamine: new selective serotonin reuptake inhibitors. Clin Pharmacol 11: 930-957.

Guillemot F, Joyner AL (1993) Dynamic expression of the murine
Achaete-scute homologue MASH-1 in the developing nervous system. Mech Dev 42:171-185.

Guillemot F, Lo L, Johnson J, Auerbach A, Anderson DJ, Joyner A (1993) Mammalian Achaete-scute homologue-1 is required for the early development of olfactory and autonomic neurons. Cell 75:120.

Ito K, Sieber-Blum M (1991) In vitro clonal analysis of quail cardiac neural crest development. Dev Biol 148:95-106.

Ito K, Sieber-Blum M (1993) Pluripotent and developmentally restricted neural-crest-derived cells in posterior visceral arches. Dev Biol 156:191-200.

Jacobs-Cohen RJ, Tamir H, Gershon MD (1994) Expression of a neuronal phenotype by neural crest-derived paraneurons (parafollicular cells) is antagonized by thyroid hormone (triiodothyronine; T3). Soc Neurosci Abstr 20:654

Johnson JE, Birren SJ, Anderson DJ (1990) Two rat homologues of Drosophila achaete-scute specifically expressed in neuronal precursors. Nature 346:858-861.

Kim KS, Wessel TC, Stone DM, Carver CH, Joh TH, Park DH (1991) Molecular cloning and characterization of cDNA encoding tryptophan hydroxylase from rat central serotonergic neurons. Mol Brain Res 9:277-283.

Koe BK, Weissman A, Welch WM, Browne RG (1983) Sertraline, 1S,4S-N-methyl-4-(3,4-dichlorophenyl)-1,2,3,4-tetrahydro-1-naphthylamine, a new uptake inhibitor with selectivity for serotonin. $\mathrm{J}$ Pharmacol Exp Ther 226:686-700.

LeDouarin N, Fontaine J, Le Lièvre C (1974) New studies on the neural crest origin of the avian ultimobranchial glandular cells-interspecific combinations and cytochemical characterization of $\mathrm{C}$ cells based on the uptake of biogenic amine precursors. Histochemistry 38:297-305.

LeDouarin NM (1982) The neural crest. Cambridge: Cambridge UP.

Leivo I, Alitalo K, Risteli L, Vaheri A, Timpl R, Wartiovaara J (1982) Basal lamina glycoproteins laminin and type IV collagen are assembled into a fine-fibered matrix in cultures of a teratocarcinoma-derived cell line. Exp Cell Res 137:15-23.

Levi-Montalcini, R (1982) Developmental neurobiology and the natural history of nerve growth factor. Annu Rev Neurosci 5:341-362.

Lo L, Johnson JE, Wuenschell CW, Saito T, Anderson DJ (1991) Mammalian achaete-scute homolog 1 is transiently expressed by spatially restricted subsets of early neuroepithelial and neural crest cells. Genes Dev 5:1524-1537.

Nishiyama I, Fujii T (1992) Laminin-induced process outgrowth from isolated fetal rat C-cells. Exp Cell Res 198:214-220.

Nunez EA, Gershon MD (1972) Synthesis and storage of serotonin by parafollicular $(\mathrm{C})$ cells of the thyroid gland of active, prehibernating and hibernating bats. Endocrinology 90:1008-1024.

Polak JM, Pearse AGE, Le Lièvre C, Fontaine J, LeDouarin NM (1974) Immunocytochemical confirmation of the neural crest origin of avian calcitonin-producing cells. Histochemistry 40:209-214.

Ramamoorthy S, Cool DR, Mahesh VB, Leibach FH, Melikian HE, Blakely RD, Ganapathy V (1993) Regulation of the human serotonin transporter: cholera toxin-induced stimulation of serotonin uptake in human placental choriocarcinoma cells is accompanied by increased serotonin transporter mRNA levels and serotonin transporter-specific ligand binding. J Biol Chem 268:21626-21631.

Russo AF, Lanigan TM, Sullivan BE (1992) Neuronal properties of a thyroid C-cell line: repression by dexamethasone and retinoic acid. Mol Endocrinol 6:207-218.

Santoro M, Rosati R, Grieco M, Berlingieri MT, D'Amato GL, Franciscis V, Fusco A (1990) The ret proto-oncogene is consistently expressed in human pheochromocytomas and thyroid medullary carcinomas. Oncogene 5:1595-1598.

Schuchardt A, D'Agati V, Larsson-Blomberg L, Costantini F, Pachnis $V$ (1994) Defects in the kidncy and enteric nervous ystem of mice lacking the tryrosine kinase receptor Ret. Nature 367:360-383.

Stemple DL, Mahanthappa NK, Anderson DJ (1988) Basic FGF induces neuronal differentiation, cell division, anf NGF dependence in chromaffin cells: a sequence of events in sympathetic development. Neuron 1:517-525.

Swiderski RE, Daniels KJ, Jensen KL, Solursh M (1994) Type II Collagen is transiently expressed during avian cardiac valve morphogenesis. Dev Dyn 200:294-304.

Tamir H, Liu K, Payette RF, Hsiung S, Adlersberg M, Nunez EA, Gershon MD (1989) Human medullary thyroid carcinoma: characteriza- 
tion of the serotonergic and neuronal properties of a neurectodermally derived cell line. J Neurosci 9:1199-1212.

Tamir H, Liu K, Hsiung S, Adlersberg M, Nunez E, Gershon MD (1990) Multiple signals leading to the secretion of 5-hydroxytryptamine by MTC cells, a neuroectodermally dervived cell line. J Neurosci 10:3743-3753.

Unsicker K, Drisch B, Otten J, Thoenen H (1978) Nerve growth factor induced fiber outgrowth from isolated rat adrenal chromaffin cells: impairment by glucocorticoids. Proc Natl Acad Sci USA 75:3-3502.
Voight MM, Laurie DJ, Seeburg PH, Bach A (1991) Molecular cloning and characterization of a rat brain cDNA encoding a 5-hydroxytryp-

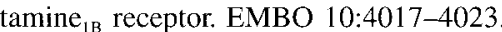

White I.A, Faton MI, Castro MC, Klose KI, Glohus MY-T, Shaw G, Whittemore SR (1994) Distinct regulatory pathways control neurofilament expression and neurotransmitter synthesis in immortalized serotonergic neurons. J Neurosci 14:6744 6753. 